\title{
EKO-PSIKOLOGI \\ KESEIMBANGAN ANTARA SAINS DAN AGAMA \\ DALAM MENCAPAI KEHORMANISAN ANTARA MANUSIA DAN ALAM
}

\author{
Kristiyanto \\ Universitas Indraprasta PGRI Jakarta \\ Kristiyanto94@gmail.com
}

\begin{abstract}
Abstrak
Dimensi agama dan prilaku manusia (behavior) mempunyai peran penting dalam merefleksi dan mengevaluasi dinamika pembangunan, sehingga tercapainya sebuah keseimbangan yang komprehensif, baik secara ekologis maupun non ekologis. Hubungan manusia dengan alam tidak akan tercapai keseimbangan, jika paradigma pembangunan yang dibangunnya tidak mencerminkan representatif kaidah-kaidah yang berlaku (hukum alam/agama). Oleh karena itu, kerusakan demi kerusakan terus mengalami peningkatan dengan tahap yang semakin mengkawatirkan, yang tentunya bentuk dan sifat kerusakan seakan telah mengarah pada tahap kerusakan jiwa (spiritualitas/psikologi) yang menjadi kunci atau benteng akhir dalam penataan peradaban yang lebih humanis dan Islami serta berkelanjutan.
\end{abstract}

\begin{abstract}
Dimensions of religion and human behavior have an important role in reflecting and evaluating the dynamics of development, so that the achievement of a comprehensive balance, both ecological and non- ecological. The human relationship with the natural balance will not be achieved, if the paradigm of development that the construction does not reflect representative applicable rules (laws of nature and religion). Therefore, one disaster after another continues to increase with an increasingly alarming stage, which is of course the shape and nature of the damage seemed to have led to the decay phase of the soul (spiritual/psychological) are the key or the final fortress in the structuring of a more humane civilization and Islamic and sustainable. Literature review and intensive observation with kontens analysis of natural and non- natural phenomena used in this study, so that the elaboration of knowledge in finding and building a conceptual can be achieved.
\end{abstract}

Kata Kunci: Sain, Agama, Keseimbangan, Eko-Psikologi 


\section{Pendahuluan}

Dinamika konsep dari proses pembangunan kini, seakan mencapai tahap kehilangan arah akan tujuan dan manfaat bagi eksistensi kehidupan makhluk hidup tak terkecuali manusia, dimana setiap ada pembangunan, selalu terdapat konsekuensi atau dampak yang merugikan baik secara materi maupun non materi. Itulah salah satu permasalahan yang perlu adanya sebuah solusi yang sesuai dengan kondisi dan situasi yang ada, tidak hanya pada tataran konsep, tetapi juga pada tataran aplikatif, sehingga perlu adanya proses elaborasi atau perpaduan yang solid dan berkelanjutan antara sains dan agama1. Sains dengan paradigma dan konsep yang dibawanya telah membawa perubahan yang masif dan komprehensif ${ }^{2}$, yang tentunya pada awalnya bagian dari khasanah keilmuan untuk mengeksplorasi sumber daya yang konstruktif dalam

1Banyak terjadi peristiwa-peristiwa penting yang berkaitan dengan sains dan agama, gagasan-gagsan rasionalisme Descartes, teori evolusi Darwin. Pada prinsipnya, perkembangan Sains tidak bermaksud ingin menghancurkan sendi-sendi kekuatan gereja sebagai sebuah konstruksi keyakinan, namun lebih kepada sebuah proyeksi perkembangan ilmu pengetahuan yang mencoba mengaktualisasikan maupun menyingkap sisisisi kebenaran yang tersembunyi. Tidak kalah dari pada itu, spekulasi yang terjadi dalam bidang Filsafatpun cukup memberikan luka yang dalam bagi Gereja, meski wilayah ini sangatlah abstrak, tidak menutup kemungkinan mengakibatkan terjadinya pertarungan intelektual yang cukup absurd. Beberapa dekade setelah Copernicus, gagasan heliosentris itu mengalami pendalaman yang cukup signifikan hingga ke ranah teori, hasilnyapun sangat mengagumban, Galileo telah sukses menjadikan teori pusatnya matahari dengan penuh meyakinkan. Meski hal itu harus dibayar mahal dengan penyiksaan fisik yang dilakukan pihak Gereja pada Galileo. Renaisans telah membentuk zaman baru dengan tergulirnya gereja ke kancah pergolatan ilmu pengetahuan, boleh jadi ini merupakan sikap Determinisme Eropa terbaik sepanjang sejarah IImu, tidak bisa di pungkiri bahwa ilmu pengetahuan telah mempengaruhi sistem pola pikir manusia sepanjang sejarahnya. Tidak peduli berapa korban yang telah bergelimpangan, namun ini merupaskan momen penting yang tak boleh dilewatkan (http://filsafat.kompasiana.com, Diunduh 17 Juni 2013).

2Perkembangan sains dan teknologi yang semakin tinggi mempunyai pengaruh langsung pada kehidupan. Pengaruh tersebut, sifatnya berbeda-beda, namun yang jelas perkembangannya mempengaruhi empat bidang yaitu: 1. Langsung ke bidang intelektual, 2. Bidang Industri, 3. Bidang politik, dan 4. Bidang Lingkungan (Lihat W.R. Kaeksi, "Pembangunan dan Kelestarian Sumber Daya Lingkungan Hidup", Forum Geografi, Nomor 19 Tahun X, Desember 1996. 
membangun peradaban manusia yang lebih bermartabat dan bermafaat bagi kehidupan manusia yang lebih layak ${ }^{3}$. Disamping itu dimensi agama, seakan ditanggalkan untuk mencapai puncaknya didalam dinamika kehidupan manusia dalam berinteraksi dengan alam, padahal agama menganjurkan untuk terus mengamati perkembangan zaman dengan seksama 4 untuk kemajuan kini dan kedepan. Semua berjalan tanpa adanya sebuah permasalahan yang muncul dan masyarakat terus

3kajian lebih mendalam serta komprehensif mengenai sains alamiah yang membantu upaya umat manusia dalam mengeksploirasi alam semesta dan seisinya, baik yang bernyawa/animate maupun yang tidak bernyawa/inanimate yang telah diciptkan oleh Allah Al-khaliq menjadi bekal untuk mengemban amanah sebagai Khalifah-Nya didunia dengan kualitas pengelolaan dengan membawa rahmat dan ridho-Nya serta kajian lain mengenai Al-Qur'an sebagai kumpulan wahyu yang diturunkan kepada Nabi Muhammad SAW, untuk disosialisasikan ke seluruh umat didunia berupa agama Islam yang universal melalui proses dakwah dan keteladanan berkesinambungan yang dokumentasinya terhimpun dalam Sunnah, menunjukkan adanya keserasian dan berpotensi simboisis mutualistis antara kedua kajian itu dan bukannya dikotomi yang saling bertentangan (Baqir et. all, Integrasi IImu dan Agama: Interpretasi dan Aksi (Bandung: Mizan Pustaka, 2005).

${ }^{4}$ Pengembangan sains dalam sejarah Islam sejalan dengan perintah Alquran untuk mengamati alam dan menggunakan akal, dua dasar metodologis sains. Alquran sendiri merupakan sumber pertama ilmu, seperti yang dinyatakan dalam Surat An-Nisa' ayat 82, "Maka apakah mereka tidak memerhatikan Alquran? Kalau kiranya Alquran itu bukan dari sisi Allah, tentulah mereka mendapat pertentangan yang banyak di dalamnya." Perintah penggunaan akal sebagai dasar kerasionalan ilmu dengan perintah mengamati alam sebagai dasar keempirikan ilmu selalu berjalan seiring, misalnya dalam Surat Ar-Rum ayat 22, Al-Baqarah ayat 164, Ali Imran ayat 190-191, Yunus ayat 5, dan Al-An'am ayat 97. Firman Allah SWT juga sering disertai pertanyaan afala ta'qilun (mengapa tidak kau gunakan akalmu) dan afala tatafakkarun (mengapa tak kau pikirkan). Perintah Alquran itu diperkukuh oleh hadits-hadits Nabi SAW yang mewajibkan umat Islam untuk menuntut ilmu. "Menuntut ilmu itu wajib bagi kaum muslimin laki-laki dan perempuan." (HR Bukhari dan Muslim) dan "Tuntutlah ilmu semenjak dari ayunan sampai ke liang lahat." (HR Bukhari). Kedudukan para ilmuwan dalam Islam dipandang utama, seperti dinyatakan Rasulullah SAW dalam hadits, "Manusia yang mulia adalah seorang Mukmin yang berilmu." (HR Bukhari). Ini sesuai dengan pernyataan Allah SWT dalam Surat AlMujadalah ayat 11, "Allah tinggikan beberapa derajat kedudukan orang yang beriman dan berilmu." Bahkan Rasulullah SAW menegaskan bahwa, "Manusia yang paling dekat derajatnya dengan derajat para nabi adalah orang-orang yang berilmu dan berjuang." (HR Bukhari) (http://www.republika.co.id/berita/dunia-islam/khazanah/12/02/06/lyyhx1-tradisisains-dan-teknologi-dalam-sejarah-islam-1, Diunduh 17 Juni 2013) 


\section{Kristiyanto}

mengalami kemajuan dalam berbagai bidang keilmuan, yang kemudian muncul sebuah penciptaan teknologi yang kini semakin modern dan canggih dalam berbagai dimensinya fungsi dan dampaknya. Kemajuan dengan perkembangan sains dan teknologi, menciptakan sebuah khasanah keilmuan baru pada pandangan manusia terhadap alam sekitar, sehingga dengan kamajuan tersebut, manusia mengganggap paling berkuasa atas semua5. Bahkan manusia mengklaim, bahwa sains adalah segala-segalanya dan dengan sains mampu memecahkan segala permasalahan yang ada. Kemajuan tersebut, secara umumnya diakui bersama merupakan tuntutan dan tantangan untuk terus diusahakan dengan semaksimal mungkin, bahkan semua agamapun mengharuskan umatnya untuk terus tumbuh dan berkembang didalam kehidupannya, yang tentunya mempunyai dampak positif dalam proses kehidupannya yang sesuai dengan arahan dan pedoman dalam kitab sucinya masingmasing.

Hubungan manusia dan alam ${ }^{6}$, secara tidak langsung kini mengalami sebuah dilema didalam hubungan atau interaksinya, sehingga perlu adanya re-interpretasi agar tercipta sebuah keseimbangan dalam

5Manusia adalah tanahan alam, tapi ia akan menjadi bebas ketika ia menjadi manusia sepenuhnya. Dalam pandangan Al-kitab dan Yahudi selanjutnya, kebebasan dan kemerdekaan adalah tujuan perkembangan manusia, dan niat dari tindakan manusia adalah proses tetap dari pembebasan satu dari kungkungan yang mengikat manusia dari masa lalu, alam, pada suku dan pada berhala (E. Fromm, Manusia Menjadi Tuhan: Pergumulan Tuhan Sejarah dan Tuhan Alam (Yogyakarta: Jalasutra, 2011).

6Kajian hubungan atau interaksi manusia dan alam, dapat dibahas dari berbagai latar belakang keilmuan yang beragam (multidisiplin), tetapi sesuai dengan latar belakang penulis, secara umum dapat dikaji dari perspektif ilmu ekologi. Model ilmu tersebut, melihat dari dampak dari hasil hubungan keduanya, yang tentunya akan membuahkan sebuah konsep yang dapat menjustikasi dampak dari interaksi tersebut. Artinya apakah bersifat merugika, tidak merugikan, saling menguntungkan, atau tidak berdampak sama sekali. Hal tersebut, dapat diperkuat dengan konsep dari Hadi terkait dengan kaidah ekologi yaitu karakteristik lingkungan hidup manusia berkaitan erat dengan ekologi lingkungan alam yang terdapat disekitarnya. Disamping itu, Soemerwoto, mengungkapkan bahwa ilmu tentang hubungan timbal-balik mahkluk hidup dengan lingkungan hidupnya disebut ekologi. Oleh karena itu permasalahan lingkungan hidup pada hakekatnya adalah permasalahan ekologi (O. Soemarwoto, "Ekologi, Lingkungan Hidup dan Pembangunan" (Jakarta: Djambatan.1994). 
interaksinya (Hubungannya). Secara historis, ketidakstabilan hubungan tersebut, terpacu sebagai akibat dari dampak paradigma revolusi industri dan paradigma pembangunan yang selalu mengalami perubahan dan perkembangan. Paradigma tersebut, kini telah merambah diberbagai wilayah dunia global, dengan membawa perubahan diberbagai aspek lini kehidupan manusia. Kemudahan akan akses dan melintas batas geografis bagian dari perkembangan sains dan teknologi yang kini menjadi tumpuhan besar dalam mengelola dan memanfaatkan sumber daya yang ada didalam maupun permukaan bumi. Hal tersebut, tentunya menjadi kesuksesan tersendiri bagi manusia yang berakal, sehingga tidak mengherankan akan kemajuan yang kini dinikmati dan dirasakan. Segala sesuatu yang telah diraih manusia, tentunya menjadi sebuah refleksi ulang atau re-evaluasi dalam menjalankan sebuah hubungan yang dinamis dan tentunya mengarah pada keberlanjutan atau eksistensi antara manusia dan alam. Apakah fenomena tersebut, sudah mengarah pada tujuan itu? Inilah yang perlu digali dan dibedah akan hubungan manusia dan alam yang mempunyai siklus yang mulai berseberangan atau bertentangan. Apapun yang kini, telah diraih atau dicapai sebuah peradaban modern, tentunya diharapkan tidak mengurangi sensitifitas rasa sebagai manusia yang juga bagain dari alam dalam berhubungan dan berinteraksi.

Keberhasilan manusia didalam memahami fenomena alam atau bersifat fisik, sepatutnya menjadi bagian dari rasa sensitifitas sebagai manusia yang juga mempunyai insting. Sebagaimana yang diketahui manusia mempunyai keunggulan dalam panca indera dibanding dengan jenis makhluk hidup lainnya, tetapi dinamika dengan paradigma pembangunan yang terus berubah dan berkembang, telah membelenggu keunggulan tersebut. Potensi manusia sebagai Khalifah, seakan sudah kehilangan arah akan rasa tanggung jawabnya untuk selalu menjaga dan memelihara lingkungan secara berkelanjutan. Dimensi manusia7, sedikit

7Filsafat manusia adalah gambaran menyeluruh atau sinopsis tentang realitas manusia. Berbeda dengan ilmu-ilmu tentang manusia, filsafat manusia tidak menyoroti aspek-aspek tertentu dari gejala dan kejadian manusia secara terbatas. Aspek-aspek seperti kerohanian dan kejasmanian, kebebasan dan determinisme, keilahian dan 


\section{Kristiyanto}

diuraikan dalam ilmu filsafat, memang sangat sulit diuraikan secara detail dan kompleks, karena sifatnya yang dinamis, disamping banyak dipengaruhi kondisi dan situasi lingkungan sekitar, baik secara lokal, regional, maupun global. tentunya ini menjadi kajian menarik untuk memahami perubahan lingkungan dikaji dari aspek prilaku manusia sebagai agen utama dalam dinamika perubahan tersebut. Untuk itulah aspek manusia dilihat dari ilmu psikologi sangat penting dalam mendukung dalam mengukur hubungannya secara detail. Keterkaitan tersebut, sangat ditentukan dari dampak prilaku manusia dalam arti dari dimensi budaya yang tercipta, yang tentunya akan mempengaruhi persepsi dan interpretasi manusia terhadap alam sekitar.

Kajian-kajian tentang dimensi manusia, terkait aspek psikologie, sudah banyak dilakukan hampir beberapa abad lamanya walaupun tanpa tersadari dan berkembang hingga masa kini, tetapi belum sampai pada tataran implementasi atau praktek, sehingga sulit mengukur parameter

keduniawian, serta dimensi-dimensi seperti sosialitas dan individualitas, kesejarahan dan kebudayaan, kebahasaan dan simbolisme. Semuanya itu ditempatkan dalam kesatuan gejala dan kejadian manusia, yang kemudian disoroti secara integral oleh filsafat manusia. Ini berarti bahwa filsafat manusia mencakup segenap aspek dan ekspresi manusia dan lepas dari kontekstualitas ruang dan waktu (universal). Karena filsafat manusia bersifat sinopsis dan universal, mencakup segenap aspek dan dimensi yang terdapat dalam realitas manusia, maka ia tidak mungkin bisa mendeskripsikan semuanya secara rinci dan detail (Z.Abidin, Filsafat Manusia: Memahami Manusia Melalui Filsafat (Bandung: Remaja Rosdakarya, 2003).

8Psikologi adalah termasuk ilmu baru yang mulai berkembang di akhir abad 19 didaratan Eropa yang kemudian berkembang pesat di abad 20 di Amerika. Di Indonesia ilmu ini juga banyak menarik peprhatian masyarakat sejak tahun 1970-an. Dilihat secara etimilogis, psikologi memang mengkaji masalah-masalah kejiwaan. (psyche= jiwa, logos = ilmu). Tetapi dalam perkembangannya psikologi lebih memfokuskan pada gejala-gejala atau manifestasi jiwa itu sendiri pada dataran perilaku. Psychology is a science of behavior. Karena objek "jiwa" dianggap terlalu abstrak, maka psikologi dimulai dengan mengkaji persoalan-persoalan psikofisik, yaitu aspek fisik yang berkaitan dengan psikis. Misalnya masalah penginderaan (sensasi), persepsi, emosi atau 4 kognisi. Melalui eksperimen-eksperimen yang canggih, bidang ini berkembang dengan pesat. Salah satu konsep yang saat ini sangat populer adalah emotional intelligence (http://psikologi. ugm.ac.id/uploads/resources/File/Database\%20Penelitian\%20Dosen/reposisi_psikologi_is| ami.pdf, Diunduh 17 Juni 2013) 
atau indikator prilaku manusia yang sangat dinamis. IImu psikologi termasuk ilmu yang baru berkembang, tetapi secara aplikatif sudah terimplementasikan dalam kehidupan masyarakat lampau hingga masyarakat kini. Sampai kini belum banyak metodologi yang mengkaitkan antara prilaku manusia terhadap dampak yang ditimbulkan lingkungan sekitar, tetapi hanya sebatas kajian mendasar dan belum mengena langsung akan dinamika dimensi manusia kini dan kedepan. membahas dimensi manusia sangatlah kompleks dan rumit, disamping itu dimensi manusia mempunyai peran dan fungsi yaitu mempengaruhi dan dipengaruhi lingkungan sekitar. Seiring makin berkembangnya metodologi yang dipakai dalam menganalisi sebuah fenomena yang terjadi, tentunya menjadi titik balik untuk merumuskan sebuah indikator untuk mengevalusi dan merefleksinya, sehingga muncullah istilah ilmu psikologi. Ilmu psikologi mempunyai sebuah perjalanan yang panjang dalam perkembangannnya, apalagi dikaitkan dengan ilmu sains, seperti ekologi dan lebih empiriknya pada lingkungan. Untuk lebih jelasnya, akan dibahas secara mendalam, bagaimana perkembangan dan perubahannya sebagai ilmu yang dinamis dalam mencari dan merumuskan sebuah solusi yang berakar dari hubungan antara manusia dan alam. Sejauh ini, bagaimana bagaimana hubungan ilmu psikologi dan ilmu ekologi dalam perkembangannya? Tentunya belum banyak mengkajinya, walaupun secara tidak langsung telah terjadi sebuah integrasi keilmuan yang dinamis. ${ }^{9}$ Disamping itu ada sebuah istilah "EkoLinguistik"10 dan banyak istilah-istilah lain dalam

${ }^{9}$ Kajian dalam naskah ini, bagian dari proses pemahaman tentang dimensi manusia yang dilihat dari aspek psikologisnya, kemudian dielaborasi atau dikawinkan (yang diistilahkan oleh Prof. Dr Mujib, pakar psikologi Islam UIN Jakarta saat proses perkualihan, 2012-2013) dengan ilmu ekologi, yang tentunya belum banyak yang mengkajinya secara mendalam dalam menemukan sebuah konseptual yang tepat sesuai dengan paradigma yang berkembang. Disini penulis, ingin mencoba mengeksplorasi lebih dalam mengenai elaborasi khasanah kedua keilmuan tersebut, tentunya ini juga bagian dari proses integrasi keilmuan yang kini menjadi wacana yang menarik untuk dikaji dan didalami substansi dan dampaknya terhadap perkembangan ilmu.

${ }^{10}$ Ekolinguistik, menurut Einar Haugen, merupakan kajian interdisipliner yang melihat tautan antara ekologi (ekosistem), dan linguistik (ilmu bahasa). Dalam pembahasannya, dan sifatnya yang interdisipliner, kajian ini melibatkan kajian-kajian lain, 
mewacanakan sebuah konsep yang mampu membangun sebuah proses kehidupan yang harmoni dan seimbang. Tetapi istilah tersebut, tidak akan dibahas dalam kajian ini, karena sedikitnya ruang untuk memaparkan secara komprehensif, karena terkait dengan dinamika bahasa yang digunakan sehari-hari dalam mempersepsikan alam sekitar.

Membahas atau mengkaji istilah "Integrasi"11 tentunya mempunyai konsekuensi yang panjang akan tujuan yang dicapainya, dalam hal ini perlu adanya pemahaman bersama dalam menciptakan sinergitas yang membangun dalam arti mampu bekerjasama secara terintegrasi. Integrasi

diantaranya, sosiologi, antropologi, psikologi, dan ilmu politik. Selain aspek sosial, ekolinguistik, menurut Mühlhäusler, mempertimbangkan aspek ekologis bahasa yang dipakai penutur dalam sebuah masyarakat. Aspek sosial-ekologis sangat memengaruhi keterpeliharaan, keseimbangan, dan keterwarisan lingkungan bagi generasi mendatang. Ekolinguistik, atau ekologi bahasa, berusaha mewujudkan lingkungan yang sehat, dengan memasukan kearifan-kearifan ekologis lokal ke dalam bahasa tersebut. Unsur-unsur bahasa yang dimaksud, adalah eko-fonologi, eko-morfologi, eko-sintaksis, dan ekosemantik, yang menjadi bagian dari wacana lingkungan. Mengingat pentingnya peran, dan fungsi sosio-ekologis dalam wacana-wacana teks lingkungan, ke depannya, pengkaji bahasa, khususnya ecolinguist, pemerhati, aktivis, dan pengambil keputusan terkait lingkungan, serta pelbagai pihak harus mempertimbangkan sosio-ekologis yang dimiliki masing-masing etnik yang ada di Aceh. Sudah barang tentu, sembilan etnik di Aceh memiliki konsep sosio-ekologis yang berbeda. Belum lagi, ungkapan-ungkapan terkait dari sebelas bahasa daerah di Aceh. Sekiranya, konsep tersebut diberdayakan, akan tercipta sinerjisitas, dan harmonisasi dalam penyelamatan lingkungan Aceh. Terlebih lagi, dalam mewujudkan lingkungan Aceh yang sehat, seimbang, dan terwaris melalui Aceh Green Vision(http://sosbud.kompasiana.com/2010/01/08/\%E2\%80\%98greenspeak\%E2\%80\%99menuju-keseimbangan-lingkungan-50248.html, Diunduh 17 Juni 2013).

${ }^{11}$ Integrasi ilmu agama dan ilmu pengetahuan umum menjadi hal yang sangat diperlukan. Dikotomi terhadap keduanya sebaiknya dihindari. "Integrasi ilmu merupakan keniscayaan yang perlu dicapai dari kajian perbandingan antar ilmu-ilmu itu, misalnya antara yang dikenal dengan ilmu agama dan ilmu umum," kata guru besar Universitas Islam Negeri (UIN) Syarief Hidayatullah Jakarta, Ahmad Sukardja, dalam menyambut acara syukuran purnabakti usia 70 tahun dirinya di Jakarta, Selasa (9/10) malam. Sukardja menjelaskan, sumber ilmu yang dikenal manusia saat ini dikelompokkan pada dua sumber, vertikal dan horisontal. Sumber ilmu vertikal adalah wahyu Tuhan. Sementara sumber ilmu horizontal adalah manusia dan lingkungannya (http://www. republika.co.id/berita/nasional/umum/12/10/10/mboczu-integrasi-ilmu-agama-dan-umumdiperlukan, Diunduh 17 Juni 2013). 
keilmuan ${ }^{12}$ sebuah konsep yang mampu menjembati atau mediasi dari problematika yang semakin rumit dan kompleks dalam mewacanakan sebuah isu yang semakin panas dan bersifat mengglobal dalam peradaban manusia kini. Tentunya tidak mudah dalam membedah akan hubungan tersebut, tetapi ini merupakan sebuah tuntutan yang harus dilakukan dalam tahap pencarian sebuah konsep atau solusi yang tepat dalam mempersepsikan fenomena yang terjadi kini dan kedepan. Sepatutnya kajian keilmuan yang terintegrasi menjadi wacana yang secara konsisten dan berkelanjutan terus dipupuk serta dipahami bersama dalam dinamikanya.

\section{Dinamika Hubungan Antara Ekologi dan Psikologi dalam Perkembangannya}

Elaborasi dan kolaborasi dalam berbagai bidang keilmuan sangat perlu dilakukan dan diintensifkan dalam merumuskan sebuah keputusan yang mampu memberi kontribusi dan solusi yang akurat, walaupun tidak sampai $100 \%$. Hal tersebut, terkait dengan permasalahannya yang kompleks dan dinamis, sehingga perlu adanya sebuah penelitian yang panjang dan berkelanjutan. Sejauh ini, perubahan dan perkembangan ilmu mengalami pertumbuhan dan perkembangan, terutama dalam metodologinya, tentunya ini menjadi kabar yang menarik untuk diikuti dan dipahami akan dinamikanya. Diketahui bersama, bahwa perkembangan ilmu, akan selalu diikuti dengan perubahan-perubahan baik secara sosial, budaya, ekonomi, dan teknologi terapan serta sebagainya. Itulah yang menjadi masalah pokok, timbulnya kompleksitas permasalahan yang makin rumit dicari dan dipahami secara komprehensif dan terintegrasi. Dinamika perkembangan keilmuan yang terus melaju, sangat terkait dengan

\footnotetext{
${ }^{12}$ Mengkawinkan dua keilmuan atau lebih, merupakan sebuah proses untuk menemukenali atau membangun konseptual yang adaptatif dan persesuasif, dalam arti mampu memahami dan mengikuti perkembangan serta perubahan ilmu yang terus berjalan atau dinamik. Elaborasi bagian dari proses pemahaman dinamika keilmuan yang komprehensif dan terintegrasi, sehingga tidak muncul gap-gap atau kemandegan dalam mengembangkan khasanah keilmuan yang lebih up-date.
} 
perubahan paradigma yang dibangun manusia kini, ini mengindikasikan bahwa paradigma menjadi parameter perkembangan dari metodologi.

Sebagaimana yang dipahami bersama, bahwa kajian dimensi manusia tidak hanya seputar wacana saja, tetapi sudah mengarah pada perubahan sikap yang aplikatif, tetapi yang menjadi titik lemah dalam bentuknya adalah sulitnya mengukur prilaku manusia dalam berinteraksi dengan alam sekitar. Kajian ekologi mencoba untuk menulusuri prilaku manusia secara empirik, dimana mengarah pada sifat-sifat dari dampak yang ditimbulkan atas hasil interaksi antara manusia dan alam sekitar. Alam sekitar ini, mencakup keseluruhan sistem atau daur energi maupun non energi yang berjalan secara natural dan unnatural. Tentunya ini menjadi bagian yang belum tersentuh oleh perkembangan sains yang hanya menitik beratkan pada teknik pengelolaan dan penggunaan yang optimal dengan teknologi saja, sehingga perlu adanya kajian kolaborasi dari berbagai bidang keilmuan, terutama kajian ekologi dan kajian psikologi. Dua keilmuan tersebut, penulis mencoba untuk re-kolaborasi untuk mengevaluasi fenomena yang sangat terkait dengan ketimpangan atau ketidakseimbangan dinamika siklus alam maupun manusia didalam kehidupannya.

Konsekuensi dari elaborasi dan kolaborasi keilmuan tersebut, telah membawa khasanah baru untuk lebih memahami kompleksitas permasalahan yang makin carut marut akan kepentingan dan ketergantungan manusia terhadap sumber daya alam. Selama ini, belum banyak kalangan ilmuwan sains mengeksplorasi lebih dalam akar dari permasalahan yang timbul, disamping itu peran agama didalamnya tidak banyak dijadikan referensi utama, sehingga hubungan Manusia, Alam, dan Tuhan seakan memudar. Sepatutnya kajian ekologi menjadi model dari perkembangan kajian psikologi yang mengarah pada pemahaman keBesaran Tuhan sebagai pencipta dan penyebabnya. Kajian ekologi dan psikologi belum banyak menyandingkan pemahaman yang komprehensif dalam menata dinamika alam yang harmonis dan keberlanjutan.

Seiring perkembangan akan pemahaman kompleksitas permasalahan yang ada disekitar, tentunya menjadi pertimbangan penting 
untuk lebih mensinergiskan sebuah metodologi yang komprehensif dari beragam khasanah keilmuan. Dengan begitu, diharapkan adanya pembahasan yang kolaboratif, sehingga timbulnya sebuah keseimbangan antara sains dan agama dalam membangun sebuah keharmonisa hubungan manusia dan alam. Itulah sebuah konsep teoritik yang perlu dibangun dalam paradigma pembangunan kini dan kedepan. Disamping itu mampu menjadi media informasi yang mampu membangun sebuah kesadaran bersama dalam hidup yang penuh berkah dan saling mengisi. Kini perkembangan akan kajian fenomena alam maupun non alam (sosial), sudah banyak dilakukan diberbagai kalangan pemikir baik dalam forum nasional, bahkan sampai ketingkat internasional ${ }^{13}$.

Kajian psikologi, dikaitkan dengan kerusakan atau ketidakseimbangan lingkungan sebuah metodologi yang termasuk dalam khasanah ilmu baru, tentunya untuk mengetahui atau mencari parameter dari dimensi manusia dilihat dari aspek kecenderungan atau motivasi manusia dalam berinteraksi dengan lingkungan sekitar. Selama ini, terasa dan terlihat secara tidak langsung hubungan manusia dengan alam menjadi dilema yang kini belum menemukan sebuah solusi yang sesuai dan seimbang. Dinamika tersebut, telah mencapai puncaknya, maka terjadilah sebuah bencana yang intensitas dan durasinya makin meningkatnya. Sejauh mana, peran yang dimainkan oleh ilmu psikologi untuk berkontribusi memperbaiki atau merestorasi lingkungan kini dan kedepan? tentunya ini menjadi tantangan dalam mencari parameter yang sesuai dengan fenomena yang ada. Kolaborasi sebuah keilmuan, tentunya menjadi bagian dari dinamika dalam mencari sebuah konsep (teoritis) yang mampu mengubah paradigma pembangunan, kemudian mengubah arah pada tataran praktek yang diharapkan. Kajian "Eko" dan "Lingkungan"

${ }^{13}$ Manusia adalah mahkluk yang sadar, demikian psikologi humanistic menyuarakan secara keras titik tolak psikologinya. Manusia berbeda dengan binatang dan mesin, manusia adalah mahkluk yang mampu mengalami, mengambil keputusan dan bertindak, demikian Irvin L. Child dari Yale University. Pikiran dalam diri manusia, sebagaimana juga menjadi tema sentral dalam kisah baru, merupakan primat dalam psikologi humanistik (G. Soetomo, Sains dan Problem Ketuhanan (Yogyakarta: Kanisius, 1995), hlm. 31. 
merupakan perkembangan konsep yang dibangun atas akumulasi dari permasalahan lingkungan yang makin masif dan destruktif, yang tentunya ini menjadi kajian menarik yang perlu dipahami secara komprehensif. Kajian tersebut, tentunya sangat terkait dengan ilmu alam, seperti "Ekologi" yang tentunya sudah mengarah pada kajian pada prilaku manusia (human of behavior), lebih mudahnya disebut "Ekologi Manusia". Adapun pada bidang ilmu lainnya, yang terkait dengan kajian dalam makalah ini adalah "Psikologi" artinya prilaku manusia yang diamati, diukur, dan dinilai dari aspek motivasi yang akhirnya terwujud pada ranah kepentingan atau tujuan hidup selama ini. Inilah sebuah kajian yang menarik untuk lebih digali dan didalami peran dan fungsi manusia selama berproses hidup, yang mungkin belum banyak dibahas secara mendalam dan komprehensif serta terintegrasi.

Dilain pihak Ekologi juga kajian ilmu yang terus mengalami perubahan dalam perannya untuk mencerna segala persoalan yang terus berkembang, terutama terkait dengan prilaku mahkluk hidup, tidak hanya manusia, tetapi juga hewan, tumbuhan, dan bahkan pada level mikroorganisme. Tentunya ini menunjukkan sebuah tuntutan untuk terus mengembangkan metodologi yang sesuai dengan fenomena yang muncul, disamping mampu menjelaskan atau mendeskripsikan secara detail dan komprehensif. Kajian tersebut, merupakan sebuah sistem yang saling terkait, sehingga apapun hasil analisanya, sepatutnya tidak boleh dilihat dari satu aspek. Inilah salah satu kelemahan yang sering dialami peneliti monodisiplin, sehingga tidak membuahkan sebuah solusi yang tepat dan akurat. Ekologi bagian dari dinamika keilmuan yang kompleks dan berkesinambungan, disamping itu bagian dari kumpulan-kumpulan kajian ilmu lainnya. Ekologi sebuah kajian ilmu yang mampu menjaring dan menghubungkan ilmu lainnya, tetapi ini tergantung dari kemampuan untuk menangkap dan menganalisanya. Apalagi disandingkan dengan Psikologi yang bertautan dengan dimensi manusia secara keseluruhan. Diketahui bersama, bahwa ekologi adalah dimensi alam dan manusia, sedangkan psikologi adalah manusia, sehingga kedua keilmuan tersebut, sebuah kajian keilmuan yang saling kait-mengkait atau pengaruh-mempengaruhi 
yang selama ini belum banyak dikaji secara holistik. Tentunya ini, menjadi langkah awal untuk lebih memahami akar permasalahan yang kini belum tersentuh dan terukur secara valid atau signifikan. Sepanjang perjalanan dalam perkembangan kedua ilmu tersebut, kini bukan lagi sekedar hanya sebuah wacana atau isu belaka, tetapi sudah masuk ke ranah aplikasi atau implementasi. Sepatutnya kedua kajian dari keilmuan tersebut, mampu menjembati atau mediator dalam menginspirasi sebuah terobosan yang tepat dalam berkontribusi lebih banyak khasanah keilmuan yang lebih aplikatif, adaptif, dan persuasif. Seiring dengan perkembangan akan metodologi, tentunya menjadi titik awal untuk mengamati dinamika khasanah keilmuan yang terus melaju dengan paradigma yang dibawanya.

Paradigma pembangunan, tentunya menjadi perhatian bersama dalam melihat dan mengkaji secara komprehensif, terkait bagaimana pola pembangunan sekarang seakan telah menjauh dari keseimbangan alam. Selama ini, ketidakseimbangan lingkungan atau alam, kalau dibedah dan dianalisis akan memberikan sebuah khasanah atau menciptakan warna yang dinamis, terkait dengan perlu tidaknya sebuah metodologi yang mampu menjembati dikotomi keilmuan yang terus berjalan dalam perjalanannya. Titik temu, tentunya sulit dilakukan, ketika perdebatan mengenai fenomena yang terjadi tidak saling mengisi, tetapi saling menyalahkan. Oleh karena itu sinergitas dalam membangun paradigma yang harmoni sangat dibutuhkan dalam masa kini dan kedepan. IImu ekologi, kini mengalami sebuah kemajuan pesat, seiring dengan perkembangan permasalahan yang muncul dengan dampak yang dibawanya, disamping itu kajiannya sudah mengarah pada berbagai perspektif dan komprehensif.

\section{Kajian Ekologi dan Psikologi: Dinamika Keilmuan dalam Membangun Harmonisasi dan Keseimbangan Alam}

Pemahaman lain yang dapat ditarik dari kedua keilmuan tersebut, ilmu ekologi bagian dari keilmuan "sains" seperti yang telah diuraikan pada alinea sebelumnya, sedangkan ilmu psikologi bagian dari representasi keilmuan "agama" yang tercermin dari keyakinan atau keimanan. Selama 
ini, banyak uraian atau penjelasan yang hanya mendeskripsikan sepotongpotong fenomena yang terjadi, terutama masalah ketidakseimbangan alam atau lingkungan sebagai akibat dari paradigma pembangunan yang berkembang dan berubah-ubah. Membangun dan menciptakan sebuah bangunan yang harmonis dan penuh warna dalam interaksi antara manusia dan alam, merupakan pekerjaan yang sulit dijangkau, sehingga perlu diadakannya sinergitas antar keilmuan secara komprehensif dan kontuinitas. Menjakau dan menjelah dari akar tujuan membangun sebuah integrasi keilmuan, tentunya membawa sebuah pemahaman baru dalam menemukenali permasalahan yang terjadi. Dipahami bersama, bahwa selama ini kajian-kajian yang berkaitan dengan agama dan sains selalu bertolak belakang, dalam arti hanya melihat dari satu aspek, sehingga tidak mengherankan, jikalau hasil analisanya tidak tajam atau tidak tepat sasaran.

Membangun sebuah hubungan yang harmonis dan seimbang dalam masa-masa kini, tentunya bukan pekerjaan yang mudah. Ketidakmudahan tersebut, tercermin dari makin carut marutnya bangunan yang diciptakan manusia dalam peradabannya dalam mencapai kehidupan yang layak. Dimensi ekonomis, tentunya menjadi faktor penting untuk melihat fenomena secara komprehensif dalam mengukur dampak yang ditimbulkannya. Oleh karena itu manusia terbelenggu dengan kepentingan yang sesaat atau berjangka pendek. Eksploitasi secara besar-besaran seakan telah menjadi paradigma pembangunan kini, sehingga tanpa tersadari telah membawa sebuah ketidakharmonisan hubungan manusia dengan alam. Inilah penting untuk ditelusuri hubungan manusia dan alam dilihat dari perspektif ilmu ekologi dan ilmu psikologi. Secara runtut dan sistematis dimensi manusia harus dikaji secara komprehensif dan terintegrasi, dalam mencapai sebuah konsep yang mampu menciptakan bangunan hidup yang seimbang yang tercermin dari hubungan manusia dan alam secara harmonis.

\section{Dimensi Ekologi sebagai Sains dan Psikologi sebagai Keyakinan}

Dimensi keyakinan yang membentuk arah prilaku atau pedomanan tata cara berhubungan dengan alam sekitar merupakan bagian dari rasa 
keimanan/kepercayaan seseorang ${ }^{14}$, yang tentunya mempunyai agama (Islam maupun non Islam sekalipun). Segala bentuk intervensi manusia terhadap alam, tentunya menimbulkan konsekuensi yang mudah atau sulit terprediksi secara akurat dan detail. Instrumen yang digunakan untuk mengukur atau menilai sebuah fenomena alam, tentulah tidak mudah dilakukan, hanya saja bisa dikembangkan dengan pendekatanpendekatan yang sesuai dengan permasalahan yang muncul atau kondisi pada umumnya. Sains dengan metodologinya mengalami perkembangan yang sangat pesat dengan terobosan-terobosan barunya, sedangkan agama masih berkutat pada hal-hal yang sifatnya normatif dan monoton, sehingga sulit dilakukan langkah dalam mengelaborasi atau kolaborasi, jikalau masih saling menyalahkan dan membenarkan secara buta. Wacana mengenai adanya "Integrasi" keilmuan menimbulkan sebuah optimisme kalangan pemikir, untuk bisa bangun dari keterpurukan kemajuan sebuah metodologi yang terus berkembang, terutama di negara maju atau eropa, tentunya ini menjadi pekerjaan bersama bagi masyarakat yang beragama untuk lebih pro aktif dan mampu mengikuti dan mengasimilasinya dengan optimal. Sejauh ini, apa yang menyebabkan masih terjadinya dikotomi keilmuan yang berlanjut? Dikotomi, sepintas telah dipaparkan pada alinea sebelumnya, tetapi yang menjadi dasar dari probelmatika tersebut, terkait

\footnotetext{
${ }^{14}$ Hubungan manusia dan alam semesta merupakan sebuah tema penting filsafat. Dengan kata lain, itu adalah sebuah masalah yang sangat esensial bagi manusia, dimana ia menyimpan potensi besar dalam dirinya. Mereka yang mengkaji tema-tema llahiyat dan ingin mengetahui hubungan antara makhluk dan khalik, atau mereka yang ingin mengenal dirinya sendiri dan juga orang-orang yang ingin mempelajari metode kehidupannya baik itu dalam dimensi individu, sosial atau bahkan universal, maka mereka akan berurusan dengan masalah manusia dan alam semesta. Jika masalah ini terpecahkan, kebanyakan dari problema umat manusia akan terselesaikan. Menurut kebanyakan orang, manusia adalah manusia dan alam semesta adalah alam semesta. Padahal, ada hubungan yang sangat erat dan penuh makna antara manusia dan alam semesta. Manusia adalah satusatunya makhluk hidup yang memiliki ikatan abadi dengan seluruh dimensi alam. Seluruh bagian dan gerakan di alam memiliki hubungan satu dengan yang lain. Ada ikatan erat antara karakteristik dan fenomena-fenomena di alam ini. http://indonesian.irib.ir/artikel1/ asset_publisher/7xTQ/content/id/5208299, Diunduh 17 Juni 2013)
} 
Kristiyanto

dengan ketertinggalan dalam memahami dan mengikuti perubahan zaman yang didasari atau ditumpangi sains.

Ekologi dan Psikologi sepatutnya menjadi dua khasanah keilmuan yang dinamis dalam mendeskripsikan secara subjektif dan gamblang sebuah fenomena alam maupun non alam secara tuntas, juga perlu adanya kreativitas dan inovatifitas dalam menciptakan sebuah metodologi yang sesuai dengan keperluannya. Kedua keilmuan tersebut, seakan menjadi bagian dari representatif dari paradigma yang dibangun dan dikembangkan sesuai dengan kebutuhan zaman, tetapi bila dikaitkan dengan aspek agama sebaliknya. Dengan begitu objek yang dianalisa dalam kajian keilmuan tersebut, mengarah pada hubungan manusia dan alam dari perspektif ekologi dan psikologi untuk menemukenali titik ukur yang dapat dijadikan barometer dampak dari hubungan tersebut. Sains dan keyakinan dua paradigma yang selalu mengalami benturan dalam implementasinya, sehingga sulit mengelaborasi secara komprehensif dan terintegrasi. Perlu adanya langkah-langkah pasti dalam menyusun metodologi yang kuat untuk menemukan sebuah konsep yang jitu.

\section{Dimensi Manusia dalam Berbagai Perspektif}

Sungguh luar biasanya fenomena yang terjadi kini, terkait dengan ketergantungan manusia terhadap alam dalam kebutuhannya untuk mencapai sebuah keseimbangan baik secara jasmani dalam arti biologis maupun non jasmani (Non biologis). Banyak kajian-kajian yang membedah dimensi manusia dalam berinteraksi dengan alam, baik dalam bidang sosial, budaya, ekonomi, politik, dan tidak kalah pentingnya adalah filsafat manusia yaitu mencoba mengevaluasi kembali peran manusia dalam berhubungan dengan alam selama ini. Manusia sebagai mahkluk yang sangat dinamis, rumit, lengkap, dan mempunyai potensi untuk memilih serta potensi yang belum tergali secara detail dan komprehensif, sehingga sulit secara langsung menjustifikasi tujuan dari hidup manusia dipermukaan bumi ini. Membahas akan kepentingan dan tujuan yang ingin dicapai oleh manusia sangatlah sulit untuk memprediksinya, karena dipengaruhi kondisi dan situasi lingkungan yang dinamis. Tentunya ini 
membutuhkan banyak kacamata untuk menafsirkan dan menggali potensi yang dapat menyebabkan dampak yang ditimbulkan atas hasil kegiatan manusia selama ini. Manusia dengan segala potensi yang dimiliki, secara umum mengalami perubahan dan perkembangan yang pesat, indikator yang dapat dilihat adalah banyaknya kemajuan yang telah diraih, terutama dalam bidang sains dan teknologi yang semakin modern dari berbagai penggunaannya. Konsekuensi dari kemajuan tersebut, tentunya menjadi kajian yang perlu dibedah secara komprehensif dan terintegrasi, karena terkait dengan keberlanjutan hidup manusia yang manusiawi.

Sejauh ini, dimensi manusia telah melampau batas kemampuan alam untuk memenuhinya, sehingga perlu adanya sebuah refleksi dan evaluasi yang mendalam memahami hubungan yang sejatinya. Manusia dengan segala kemampuannya, telah membangun sebuah era yang semakin modern dengan terciptanya produk teknologi yang makin berdaya guna, seperti yang telah diuraikan pada alinea sebelumnya. Manusia bukanlah mahkluk hidup yang statis dalam arti berdiam diri ditempat, tetapi sangat dinamis dalam berbagai perspektif. Membedah dan mengekplore dimensi manusia secara obsolut, tidak mudah dilakukan atau sulit dilakukan, karena sifatnya yang sangat mobil dan berubah-ubah setiap saat. Perubahan tersebut, tergantung dari situasi dan kondisi lingkungan sekitar, dimana lingkungan mempunyai makna yang luas dari unsur-unsur dari lingkungan meliputi lingkungan biotik dan abiotik, lingkungan sosial, budaya, dan politik, lingkungan ekonomi. Dengan begitu, sangat kompleks dan rumit, jikalau memahami manusia dari satu perspektif saja. Ini menunjukkan bahwa, manusia sangat berpengaruh dan dipengaruhi oleh faktor internal dan eksternal dalam eksistensi proses kehidupannya. Dalam hal ini, dimensi manusia terkait dengan kajian ini, hanya memfokuskan dinamika manusia dari perspektif ekologi dan psikologi dalam perkembangannya.

\section{Dimensi “Eko" dan Permasalahan Lingkungan}

Mengkaji seputar permasalahan yang berkaitan dengan lingkungan, tentunya menjadi wacana yang terus berkembang ditengah-tengah 


\section{Kristiyanto}

masyarakat yang begitu beragam akan kepentingan dalam kehidupannya sehari-hari. Manusia tidak henti-hentinya berinteraksi dengan lingkungan sekitar, terutama dalam pengelolaan dan pemanfaatan sumber daya alam sekitar, sehingga lambat laun hasil atau dampak dari interaksi tersebut, akan menjadi pokok masalah yang kini terus berkembang dan berubah. Perkembangan pokok permasalahan tersebut, seiring dengan pencapaian tingkat perekonomian yang menjadi titik ukur sebuah masyarakat yang sejahtera dan maju. Hal tersebut, terkait dengan aspek lingkungan yang menjadi isu menarik untuk dikaji secara komprehensif, terkait dengan peran, fungsi, dan dampaknya terhadap kehidupan mahkluk hidup, disamping sebagai bagian dari kebutuhan mutlak dan berkelanjutan. Kini banyak para pemikir diberbagai bidang keilmuan mengkawinkan beragam kajian lintas disiplin ilmu, yang pada umumnya mencapai sebuah konsep baru dalam memaknahi situasi dan kondisi lingkungan yang dinamis. Istilah "Eko" bagian dari hasil percampuran keilmuan yang kini menjadi konsep dalam model atau pola kegiatan yang bernuansa menjaga atau melestarikan lingkungan. Kajian "Eko" menjadi pembahasan yang menarik, ketika disandingkan dengan kerusakan lingkungan sebagai akibat dari peradaban modern yaitu pola pembangunan yang hanya menitik beratkan pada ranah ekspoitasi tanpa adanya perhitungan, terkait dengan keberlanjutan atau kelestariannya.

Konsep "Eko" sebuah paradigma baru yang merupakan akumulasi dari respon dari berbagai fenomena lingkungan yang terus dinamis, disamping itu sudah banyak istilah tersebut, diaplikasikan diberbagai bidang, baik pada ranah konsep teoris maupun empiris. Konsep Eko sudah menjadi trenitas peradaban dalam pola pembangunan, yang kini sering digunakan sebagai labelitas dalam setiap produk yang dicipta. Membahas "Eko" terkait dengan aspek psikologi, tentunya sangat terkait dengan dimensi manusia, terutama dalam sifat-sifat yang mendasari manusia dalam berinteraksi dengan lingkungan sekitar, yang selama ini belum banyak disentuh oleh para pakar atau pemikir. Munculnya sebuah konsep "Eko" tersebut, tentunya sebuah gebrakan model atau pola pembangunan yang mampu mencapai sebuah konsep keseimbangan dalam siklusnya. 
"Eko" dan "Keseimbangan" merupakan perpaduan konsep yang tepat dalam merespon perubahan lingkungan dan dampaknya, sehingga dimensi manusia yang perlu dikaji terkait dengan interaksinya selama dalam kehidupannya sehari-hari.

\section{Eko-Minded. Paradigma Model Pembangunan dalam Restorasi Alam yang Berkelanjutan}

Kajian mengenai model atau pola pembangunan yang dinamis sering mengalami perubahan dan perkembangan, seiring dengan paradigma yang diusungnya. Akhir-akhir ini model pembangunan yang berbasis "Eko" menjadi wacana disetiap derap dinamika model pembangunan yang menyatu dengan alam. Istilah "Eko" seakan menjadi bomming dalam era globalisasi ini, disamping sebagai iklanisasi disetiap produk, baik dibidang industri maupun non industri. Disamping itu istilah "Eko", bagian dari kajian "Ekologi" yang mengalami perkembangan didalam kajian ilmu yang lebih aplikatif, kuratif, dan preventif didalam merespon permasalahan lingkungan yang makin destruktif. Istilah "Eko" juga mengalam perkembangan dalam pemahamannya, dimana sering terdengar istilah "Eko-Pesantren", Eko-Kampus", "Eko-Tarbiyah", "EkoEkonomi", dan lain sebagainya. Wacana tersebut, tentunya menjadi kajian yang menarik, terkait adanya sebuah kebijakan yang mengarah pada perbaikan dan peningkatan mutu lingkungan yang berkualitas, seiring dengan pemanfaatannya, sehingga terbangun sebuah pola atau model pembangunan yang berkelanjutan. Dinamika perubahan model pembangunan tersebut, merupakan akumulasi dari buah pemikiran empiris mengenai eksistensi kehidupan makhluk yang ada dipermukaan planet satu-satunya ini, walaupun ada wacana planet lain yang menjadi habitat baru dimasa depan. Variasi dalam implementasi "Eko" dalam model pembangunan kini, seakan menjadi terobosan atau solusi baru yang tepat dalam menanggapi sebuah tuntutan bersama didalam memperbaiki lingkungan, tetapi apakah tercapai sebuah paradigma pembangunan yang humanis, harmonis, dan keserasian, jikalau dimensi manusia sendiri belum 
Kristiyanto

tersentuh atau terintervensi dengan "Eko"? inilah sebuah permasalahan yang dilematis yang belum terjawab secara komprehensif.

Merespon akan pemikiran yang berkembang dalam mengimplementasikan sebuah paradigma baru, tentunya dimensi manusia sebagai agen utama dalam perubahan tersebut, terlibat langsung dalam dinamikanya, sehingga perlu adanya sebuah elaborasi dalam memahami dinamika manusia dalam mempersepsikan akan lingkungan sekitarnya. Banyak kalangan pecinta lingkungan, bahkan penggiat restorasi lingkunga, tetapi sebagian masih melakukan kegiatan yang dikatakan dapat berkontribusi dalam perubahan lingkungan. Memunculkan sebuah perubahan dalam dimensi manusia secara keseluruhan dalam menapaki sebuah kehidupan yang seirama dengan alam sangat tidak mudah, disamping aspek kepentingan dan kebutuhan yang mengitarinya.

Seiring perkembangan peradaban manusia yang penuh dengan keinginan dan kepentingan didalam mencapai sebuah capaian yang lebih meningkat dalam memenuhi kebutuhan hidup yang dinamis. Memahami dinamika masyarakat dalam era ini, tentunya menjadi wacana didalam penggunaan sumber daya yang ada disekitarnya, dimana sebagian besar jenis sumber daya yang digunakan merupakan sumber daya yang tak terbaharuhi. Tiadanya transformasi sebuah pengelolaan dan penggunaan sumber daya alam tersebut, lambat laun dapat menjadi masalah baru dalam rentang waktu yang tidak lama, seiring dengan meningkatnya jumlah populasi manusia. Beragam hasil pemikiran dan penelitian telah dilakukan dengan hasil yang mengejutkan, hal tersebut dapat menjadi peringatan bahwa ketersediaan sumber daya alam ini terbatas, disamping itu merupakan bantahan bahwa sumber daya alam yang terkandung melimpah dan tidak pernah habis. Sepintas kalau ditarik kebelakang atau sebelum adanya sebuah transformasi sosial, budaya, ekonomi, dan politik, dalam arti masih bernuansa tipologi masyarakat konvesional atau tradisional, tentunya tidak bermasalah dengan pemanfaatan sumber daya alam sekitarnya. Tiadanya bermasalah tersebut, dapat ditelusuri akan dinamika kehidupan suku Baduy sekarang, dimana proses kehidupannya sangat sederhana dan menyatu dengan alam, berbeda dengan kehidupan 
masyarakat yang sudah terintervensi dengan budaya yang maju dan modern. Proses intervensi tersebut, merupakan bagian dari langkah awal dalam mengubah sebuah budaya yang

Diakui bersama, bahwa kehidupan yang sudah berkembang dan maju, tentunya mempunyai kekurangan dan kelebihan didalam prosesnya, hal tersebut sepatutnya menjadi kajian yang berkelanjutan untuk memahaminya dengan komprehensif dan terintegrasi. Secara tidak langsung perubahan tersebut, akan mengarah pada pola atau model pembangunan yang lebih modern. Modernitas menjadi paradigma baru pada masyarakat yang sudah berbudaya tinggi, disamping telah mampu menciptakan dan mempergunakannya dalam mempermudah aspek prosesi kehidupan masyarakat tersebut. Mengkaji dinamika perubahan tersebut, sangatlah penting untuk mengetahui secara kompleks.

\section{Eko-Pembangunan: Wujud dari Buah Kesadaran Bersama}

Kebersamaan dalam memahami dan mengaplikasikan sebuah paradigma pembangunan yang sinergis dan seimbang, tentunya menjadi pekerjaan yang tidak hanya dititik beratkan pada salah satu bidang tertentu, begitu juga melibatkan peran masyarakat. Kecerdasan ekologis ${ }^{15}$ buah dari peran masyarakat pembelajar yang selalu atau mampu mengikuti paradigma pembangunan, yang kemudian mampu menganalisanya secara komprehensif. Salah satu contoh dalam perencanaan pembangunan Mall atau sebagainya, karena mempunyai dampak langsung terhadap kondisi lingkungan sekitar.

\footnotetext{
${ }^{15 K e c e r d a s a n}$ ekologis, menurut Hultkkrantz sebagaimana dikutip Sternberg, menghendaki manusia untuk menerapkan apa yang dialaminya dan dipelajarinya tentang hubungan aktivitas manusia dengan ekosistem. Kecerdasan ekologis menempa manusia menata emosi, pikiran, dan tindakannya dalam menyingkapi jagad raya. Kecerdasan ekologis dituangkan dalam bentuk sikap dan prilaku nyata yang mempertimbangkan kapasitas ekologis, dan melahirkan sikap setia kawan manusia dengan alam. Alam semesta bukan hanya sumber eksploitasi, tetapi sebagai rumah hidup bersama yang terus dilindungi, dirawat, ditata dan bukan dihancurkan (R. Utina, "Kecerdasan Ekologis dalam Kearifan Lokal Masyarakat Bajo Desa Torasiaje Provinsi Gorontalo", Prosiding Konferensi dan Seminar Nasional, Pusat Lingkungan Hidup Indonesia ke-21, 13-15 September 2012, di Mataram 2012).
} 
Mewujudkan sebuah model pembangunan berbasis "Eko" menjadi pencapaian yang diharapkan mampu mengatasi permasalahan terkait aspek lingkungan fisik, tetapi juga dapat menciptakan keharmonisan antar lingkungan dan manusia serta sebaliknya. Keseimbangan baik secara ekologis, yang mencakup aspek hidrologis, tata ruang, dan tata iklim serta sebagainya, disamping aspek-aspek yang sifatnya non ekologis, seperti sosial, budaya, ekonomi, dan politik yang mendukung proses pembangunan yang berkelanjutan. Kini pemahaman akan pembangunan berkelanjutan dalam arti bukan sekedar mampu menyediakan generasi selanjutnya, tetapi juga mampu menyeimbangkan kebutuhan baik secara jasmani maupun rohani. Pencapaian sebuah paradigma model pembangunan semacam itu, bila dikaji dengan realitas sekarang terasa sulit untuk diimplementasikan, terkait dengan kepentingan dan kebutuhan manusia yang bersifat materialistik dan hedonistik. Secara perlahan aplikatif model pembangunan yang berbasis "Eko" diharapkan mampu mengubah gaya hidup masyarakat kini secara mendasar.

Model pembangunan yang memperhatikan unsur-unsur lingkungan secara komprehensif, tentunya akan membawa konsekuensi yang mengarah pada pembangunan yang memanusia atau memuliakan, jikalau pola pembangunan tidak hanya mengeksploitasi, tetapi eksploirasi. Wujud dari model pembangunan tersebut, tercermin dari bagaimana masyarakat dalam memanfaatkan sumber daya alam untuk proses kehidupan tidak merusak, tetapi menjaga secara lestari atau menggunakannya secara bijak. Hal tersebut, tidak hanya bagi masyarakat, tetapi juga birokrasi dalam membuat kebijakan yang terkait dengan pola atau model pembangunan yang dibangun, sehingga perlu adanya kerjasama antar komponen. Mewujudkannya memang terasa tidak mudah, seiring dengan dinamika kehidupan lokal maupun global dalam mengikuti perkembangan zaman yang kini mengarah pada tuntutan yang makin meningkat, sebagai respon atau dapat pengangkuan dapat mengikuti perubahan tersebut. Mengiringi sekedar mendapat pengangkuan atau tidak ingin tertinggal dengan Negara lain, tentunya menjadi masalah sendiri, berkaitan dengan sosial budaya yang berbeda-beda. 
Durasi dan intensitas masyarakat dalam pergulatannya dengan dinamika pembangunan yang tidak bermakna, telah membawa sebuah perubahan yang mendasar, terkait dengan kajian-kajian lingkungan yang tidak hanya mengkaji dari aspek fisik, tetapi non fisik, seperti dikaitkan dengan budaya atau dimensi manusia dalam berinteraksi dengan lingkungan sekitar. Kini perkembangan dalam pemikiran, mengenai merespon dan mengimplementasikan perubahan lingkungan, tidak hanya menciptakan teknologi atau mengembangkan metodologi belakan, tetapi akan/sudah mengarah pada restorasi diri, yang terimplementasikan pada perubahan pemikiran (minds). Doktrinasi mengenai restorasi diri mengenai kerusakan lingkungan, kini menjadi tuntutan yang tidak bisa ditunda dalam derap pola pembangunan kini dan kedepan.

\section{Khasanah Ilmu Teori ke Praktek: Terwujud dalam Implementasi}

Secara konseptual maupun teoritis, kajian-kajian mengenai kelestarian alam sudah menghiasi wacana disetiap forum-forum maupun media diberbagai belahan dunia. Hal tersebut, sepatutnya menghasilkan sebuah output yang baik, ketika diimplementasikan dalam arti bagaimana manusia berinteraksi atau berhubungan dengan alam dengan baik? Dimensi psikis manusia terhadap siklus alam, tentunya menjadi bahan refleksi maupun evaluasi yang dalam, disamping itu bagian dari kebijakan yang harus dikuatkan dengan sanksi-sanksi yang dapat membuat sadar. Bentuk aplikasi ataupun implementasi dari rumusan konsep teoritis sudah banyak dilakukan, tentunya hasilnya sangat bagus dan dinamis, tetapi yang menjadi kendala adalah bagaimana menerapkan secara real dikehidupan masyarakat yang beragam, baik dari kepentingan, sosial, budaya, ekonomi, agama, dan politik didalamnya. Secara umum agama menjadi wacana atau isu yang menarik, terkait bagaimana dimensi agama mulai mempertanyakan kembali sains dalam peran dan fungsinya.

Dinamika hubungan agama dan sains mengalami fluaktuasi dalam perkembangannya, seakan mempunyai arah dan tujuan yang berbeda, hal tersebut, sepatutnya menjadi pertimbangan dan pemikiran yang serius. Agama tidak hanya bersifat formatif, tetapi perlu langsung dipraktekkan 


\section{Kristiyanto}

dalam kehidupan sehari-hari, sehingga khasanah keagamaan dapat dirasakan dan diraba akan fungsinya sebagai pedoman atau petunjuk dalam berinteraksi terhadap makhluk lainnya. Selama ini, dipahami bersama, bahwa agama bersifat parsial, dalam arti hanya bergelut dengan penafsiran tanpa adanya sebuah fleksibilitas dalam memahaminya, sehingga muncul pemahaman taqlid (membabi buta). Hal tersebut, salah satu bagian dari terpisahnnya sebuah pemahaman yang komprehensif menjadi pemahaman yang parsial atau terkotak-kotak. Model pemahaman tersebut, menjadi awal munculnya keterpihakan atau kepentingan manusia dalam memahami dinamika alam, dimana sentuhan-sentuhannya hanya berlandaskan pada sains dan teknologi. Secara umum bentuk implementasi dari perkembangan dinamika teori atau konsep ke ranah praktek yang lebih aplikatif sudah sepatutnya tidak hanya menjadi wacana, tetapi benar-benar dilakukan, terkait bagaimana meraih sebuah hubungan manusia dengan alam yang bernafaskan agama. Dengan begitu, solusi yang tepat dalam memecahkan permasalahan pada era ini adalah, mengarah pada aspek implementasi yang kondusif dan persuasif.

\section{Kesimpulan}

Paradigma pembangunan yang diusung pada era ini, secara tidak langsung telah mengarah pada sifat yang destruktif dengan sifat yang makin masif, baik intensitasnya maupun durasinya. Tentunya ini, membawa sebuah malapetaka besar bagi kelangsungan mahkluk hidup secara keseluruhannya. Parameter yang dapat menjadi tolak ukur dari masalah tersebut, terilustrasi adanya ketidakseimbangan dalam memanfaatkan sumber daya yang ada, ekspolitasi secara besar-besaran seakan menjadi agenda dari kebijakan, baik dari pemerintah pusat maupun daerah. Disamping itu, fenomena tersebut, seiring dengan semakin berkembangnya sains dan teknologi yang tercipta selama ini, tidak terpungkiri membawa sebuah dampak yang luar biasa dalam kehidupan manusia dan berbagai lini. Sebuah bencana yang besar, bilamana tanpa adanya sebuah pencegahan yang pasti, yang tentunya membutuhkan sebuah solusi yang tepat. Banyak kajian-kajian yang mencoba memahami- 
nya, tetapi sampai kini masih sebatas permukaan, sehingga masalah terus ada, sebelum masalah pokoknya belum tuntas.

Pembangunan yang berbasis "Eko" kini mulai berkembang ditengahtengah masyarakat modern, dimana konsep tersebut, diharapkan mampu mencegah dan minimalisir dampak dari proses pembangunan. Sampai kini, belum ada instrumen yang sesuai dan valid 100\% digunakan mengukur dampak dari pembangunan. Dilain pihak perkembangan ilmu ekologi dan psikologi mengalami kemajuan yang sangat pesat, dimana sudah mengarah pada kajian-kajin yang elaboratif dan komprehensif. Sepatutnya ini menjadi harapan untuk bisa membedah permasalahan pembangunan secara tuntas atau berdasarkan penyebab akar permasalahan. Harapan kedepan, terkait dengan model atau pola pembangunan adalah mewujudkan sebuah paradigma pembangunan yang harmonis dalam arti tiadanya masalah besar dan merugikan baik secara materi maupun non materi.

Keseimbangan terwujud, bilamana terjadinya keseimbangan antara sains dan agama, yang selama ini selalu mengalami benturan dalam berbagai paradigma yang berjalan. Untuk itulah "Eko-Psikologi" menjadi wacana yang konseptual dalam meraih sebuah paradigma pembangunan yang diidamkan untuk masa kini dan kedepan. Secara otomatis proses kolaborasi dan elaborasi dari berbagai disiplin keilmuan menjadi khasanah dinamika dalam perkembangan ilmu dari berbagai perspektif. Sepatutnya proses "Integrasi Keilmuan" menjadi agenda yang perlu dikuatkan kembali, karena akan dapat membuahkan sebuah konseptual yang sampai pada tataran teori ke empirik. Manusia dan alam menjadi bagian siklus hidup yang saling terkait dan tak terpisahkan, sehingga merajut hubungan yang harmonis akan sangat saling menguntungkan (simboisis mutualisme), yang selama ini terjadi kerengganan. Dimensi manusia perlu digali dan dieksplore dari berbagai perspektif, terutama dari filsafat manusia, sehinga dengan memahami akan peran dan fungsinya sebagai khalifah, secara otomatis akan selalu merestorasi diri dan lingkungan sekitar secara berkesinambungan dalam mempertahankan eksistensinya. 


\section{Daftar Pustaka}

Al-Goyani, U. Y. GreenSpeak, "Menuju Keseimbangan Lingkungan" Opini, 2010, dalam http://sosbud.kompasiana.com, Diunduh 17 Juni 2013.

Baqir, et. all, Integrasi IImu dan Agama: Interpretasi dan Aksi, Bandung: Mizan Pustaka, 2005.

Fromm, E., Manusia Menjadi Tuhan: Pergumulan Tuhan Sejarah dan Tuhan Alam, Yogyakarta: Jalasutra, 2011.

G. Soetomo, Sains dan Problem Ketuhanan, Yogyakarta: Kanisius, 1998.

H. S. Alikodra, Teknik Pengelolaan Satwa Liar: Dalam Rangka Mempertahankan Keanekaragaman Hayati Indonesia, Bogor: IPB Press, 2010.

"Hubungan Manusia dan Alam Semesta", dalam http://indonesian.irib.ir, Diunduh 17 Juni 2013.

Republika, "Tradisi Sains dan Teknologi dalam Islam", 2012, dalam http://www.republika.co.id, Diunduh 17 Juni 2013)

Republika, "Integrasi IImu Agama dan IImu Umum Diperlukan", 2012 dapam http://www.republika.co.id, Diunduh 17 Juni 2013.

R. Izzad, "Agama dan Sains", Opini, 2013, dalam http://filsafat. kompasiana.com, Diunduh 17 Juni 2013.

R. Utina, "Kecerdasan Ekologis dalam Kearifan Lokal Masyarakat Bajo Desa Torasiaje Provinsi Gorontalo", Prosiding Konferensi dan Seminar Nasional, Pusat Lingkungan Hidup Indonesia ke-21, 13-15 September 2012, di Mataram.

Subandi, "Reposisi Psikologi Islam". Disampaikan pada Temu Ilmiah Nasional 1 Psikologi Islam, Yogyakarta 24 September 2005, dalam http://psikologi.ugm.ac.id, Diunduh 17/6-2013.

O. Soemarwoto, Ekologi, Lingkungan Hidup dan Pembangunan, Jakarta: Djambatan, 1994.

W. R. Kaeksi, "Pembangunan dan Kelestarian Sumber Daya Lingkungan Hidup". Forum Geografi, Nomor 19 Tahun X, Desember 1996.

Z. Abidin, Filsafat Manusia: Memahami Manusia Melalui Filsafat, Bandung: Remaja Rosdakarya, 2003. 